\title{
DO ENCONTRO DE DIFERENTES A UMA FESTA DE IGUAIS: UMA ANÁLISE DA SOCIEDADE PORTUGUESA NAS FESTAS ENTRE OS SÉCULOS XV E XX
}

\author{
Pedro Henrique Victorasso \\ Mestrando em História - UNESP Assis \\ E-mail: pedro_victorasso@yahoo.com.br
}

TINHORÃO, José Ramos. Festa de negro em devoção de branco: do carnaval na procissão ao teatro no círio. São Paulo: Editora Unesp, 2012. 154 p.

A festa como temática em pesquisas é um assunto recente entre os historiadores, pois estes se interessaram pelo assunto apenas nas últimas décadas. No entanto, já é abordada há algum tempo por outros estudiosos, como os folcloristas, jornalistas e sociólogos brasileiros. O jornalista José Ramos Tinhorão, nascido em 1928 em Santos-SP, é crítico e pesquisador na área da história da música e história literária brasileira, autor de uma extensa e diversificada obra sobre temas relacionados à música e festas populares no Brasil e Portugal, com base na pesquisa histórica ${ }^{1}$.

Os textos publicados por Tinhorão tendem ao materialismo histórico. Em sua obra, é possível notar frequente denúncia sobre a alienação das classes dominantes e uma valorização das classes populares como detentoras da verdadeira cultura nacional. O autor, atravessado pelos novos paradigmas da historiografia, propõe um diálogo com outras disciplinas e utiliza uma diversidade de fontes em sua investigação que abrange desde fontes oficiais, como leis, regimentos e posturas até fontes que outrora não eram consideradas seguras pelos historiadores, como os testemunhos de contemporâneos, o teatro, a literatura de cordel e impressos (folhetos, farsas, entradas e loas).

\footnotetext{
1 Em 1953, iniciou o trabalho de jornalista profissional no extinto Diário Carioca, posteriormente trabalhou no Jornal do Brasil, Correio da Manhã, Última Hora, O Jornal, Pasquim. Tinhorão participou também da revista Veja e das redes televisivas: Excelsior, Globo, TVE (RJ) e Cultura (SP). Suas primeiras publicações foram os livros A província e o naturalismo e Música popular, ambos publicados em 1966. A partir da década de 1980 , afastou-se da imprensa e passou a dedicar-se à pesquisa histórica sobre a qual desenvolveu uma extensa obra. As informações sobre o autor foram obtidas no site: http://ims.uol.com.br/Jose_Ramos_Tinhorao/D132.
}

Oficina do Historiador, Porto Alegre, EDIPUCRS, v. 7, n. 1, jan./jun. 2014, p. 202-207 
Entre os vários assuntos por ele abordados, publicou estudos sobre os sons dos negros no Brasil e em Portugal. No ano de 1988, em Lisboa, o autor publicou Os negros em Portugal - uma presença silenciosa, no qual rompe com a ideia de que apenas a colônia recebia negros escravos, pois estes também estavam presentes na metrópole.

Na obra, objeto desta resenha, Festa de negro em devoção de branco: do carnaval na procissão ao teatro no círio, publicada em 2012, o autor amplia o tema da participação dos negros na música popular e analisa a cultura africana levada a Portugal pelos escravos e, ainda, indaga em que medida essa cultura influenciou e foi influenciada no contato com a cultura católico-lusitana.

É possível notar, com base na pesquisa histórica, que a análise das fontes tende não apenas a comprovar a participação dos negros nas festas católicas portuguesas, como também a levantar hipóteses de como se estruturava a sociedade portuguesa do século $\mathrm{XV}$ ao $\mathrm{XX}$, em todas as suas esferas.

$\mathrm{Na}$ introdução do livro, o autor comenta sobre um estudo-prefácio do tomo VII do Catálogo da Universidade de Coimbra, realizado com o intuito de abordar a diversidade populacional em Portugal e utilizou como fonte uma extensa literatura de cordel, principalmente lisboeta, dos séculos XVII e XVIII. Neste estudo não é mencionada a existência de negros no país, como se houvesse a pretensão de provocar um esquecimento coletivo sobre a participação desse grupo na formação da identidade cultural portuguesa. Ele pretende provar, valendo-se dessa mesma literatura de cordel, que os negros estavam presentes e participavam dessa vida social.

José Ramos Tinhorão inicia a obra apontando para as origens das procissões que, segundo ele, eram uma reprodução das caminhadas coletivas dos antigos pagãos aos seus locais sagrados (mágicos e sobrenaturais), sempre próximos a árvores, montes ou rios. Já para os católicos, as peregrinações tinham as mesmas características, entretanto eram direcionadas à busca de relíquias sagradas ou locais em que foram realizados milagres. Estas manifestações iriam evoluir para certa teatralização, primeiro com a presença única dos padres, depois ganhariam características populares e participação de toda a sociedade com nítido sentido de festa, as quais receberam o nome de círios e romarias.

O autor traça uma análise sobre a procissão de Corpus Christi em Portugal que, durante séculos, foi a mais variada e mais animada festa religiosa popular. Tinhorão explica o caráter festivo dessa manifestação com base na passagem bíblica da transladação da Arca da 
Aliança que, segundo ele, quando concluída a peregrinação, foi estabelecida uma aliança entre os filhos de Israel com Cristo, festejada por dias com músicas e danças.

Encenações público-ambulantes para animar a procissão eram algo comum em Portugal. Essas encenações, de início, eram desenvolvidas pelos padres para narrarem episódios bíblicos, porém, com o passar do tempo, outros devotos começaram a participar das procissões, como os membros de confrarias e dos ofícios. Assim, essa manifestação passa do interior dos templos para as ruas. Tinhorão destaca que essa abertura da procissão ao povo, sem exclusões, tinha o intuito de expandir de forma pública a mensagem de Deus. Ele destaca também a característica política por trás das comemorações na qual o Estado fazia-se presente com a oficialização da festa, possível de se notar pela obrigatoriedade da participação dos ofícios na procissão. Assim, essa manifestação funcionava como um meio de afirmação do poder do monarca. Nesse sentido, essa festa era vista como parte da identidade nacional e uma oportunidade para visualizar as camadas da sociedade que participavam da festa.

Com base na leitura de dois regimentos e informações documentais encontradas no Sumario de varia historia, de Ribeiro Guimarães, o autor analisa o caráter democrático desse cortejo, pois, além de apresentar temas relacionados às minorias étnico-sociais, também contava com a participação física das confrarias e ofícios compostos por trabalhadores e negros escravos ou forros. Segundo Tinhorão, a Igreja tinha a intenção de levar a essa massa urbana os dogmas católicos, por isso não existia preconceito nos temas. Durante a procissão, cada ofício era responsável pela preparação de um bloco, abordando um tema diferente e, segundo o autor, essa organização era semelhante às alas das escolas de samba brasileiras. Por meio de sua análise, vale ressaltar o caráter religioso e profano do cortejo.

Nas danças teatrais eram ilustrados episódios bíblicos e histórico-político-sociais do país e era possível notar a forte influência árabe nessas manifestações. O caráter musical da procissão, a mistura, os contrastes no público participante da festa, assim como os escândalos e indecências encontrados em relatos levam o autor, novamente, a comparar essa procissão com o carnaval brasileiro.

Segundo o autor, essa característica democrática da festa perdeu força durante o reinado de D. João V, pois o cortejo passou a exaltar a pompa e a participação da família real, os ofícios nesse período não tinham representação física, pois eram representados pelas suas bandeiras. Após a morte do monarca, aos poucos, a festa retomou o caráter popular, mas algumas manifestações locais foram perdidas em razão do olhar severo da aristocracia. A tradição do Corpus Christi manteve-se até início do século, mas, por causa do rigor das

Oficina do Historiador, Porto Alegre, EDIPUCRS, v. 7, n. 1, jan./jun. 2014, p. 202-207 204 
autoridades da Igreja, o cortejo perdeu o caráter espetacular de festa. Percebe-se, então, a volta do espírito religioso-pagão no qual, fora da Igreja, o povo se refugiaria nos eventos paralelos dos círios e romarias.

Uma das principais preocupações do autor é esclarecer que, ao longo do tempo, a Igreja Católica incorporou elementos dos antigos pagãos aos seus ritos litúrgicos, como se pode visualizar nas procissões. Em geral, as procissões eram organizadas pela Igreja, com caráter ritual e religioso, já os círios e romarias eram manifestações de devoção comunitária para a prática de culto votivo em clima de festa. As procissões respeitavam o calendário da Igreja, ao passo que os círios e romarias resultavam da iniciativa de grupos particulares, que, por exemplo, queriam pagar promessa por milagres recebidos. Outra diferença é que as procissões localizavam-se no espaço urbano, já os círios e romarias se deslocavam em massas para santuários ou locais de culto, às vezes fora da cidade. Como citado anteriormente, a procissão mais popular em Portugal foi a de Corpus Christi, já os dois círios mais populares e mais antigos eram os dedicados a Nossa Senhora de Atalaia e a Nossa Senhora do Cabo.

Estes círios apontam fortes indícios da continuidade de uma antiga forma de religião, uma herança pagã, mal ocultada por trás da aparência de fé católica. Essas manifestações pregavam a obediência a um voto coletivo, então, em certas datas, caminhavam até os santuários geralmente próximos a locais ermos e depois de cumprido o compromisso eram celebradas festas e jogos em comemoração, assim como na tradição pagã. Desse modo, tanto os ritos da Igreja quanto as manifestações populares deixavam claro a permanência de costumes pagãos.

$\mathrm{O}$ autor afirma que "Do ponto de vista das cidades, as festas religiosas constituíram sempre, antes de qualquer coisa, uma oportunidade de gozo do lazer" (TINHORÃO, 2012, p. 83). Aponta ainda que, no período abordado, faltava uma legislação trabalhista e os nobres e a burguesia procuravam explorar ao máximo o trabalho pago; já os explorados tentavam gastar o mínimo de energia no cumprimento das tarefas. Tinhorão analisa a existência de um clima de luta de classes, cuja única forma de escapar a essa tensão era a suspensão temporária do conflito. Sendo assim, um tempo livre era cedido aos trabalhadores para a prática do lazer, mas que era concedido apenas pelo poder político do Estado ou pelo poder espiritual da Igreja.

Segundo o autor, nos dois círios destacados anteriormente, é possível compreender uma diferença de classes sociais entre seus participantes. O círio de Nossa Senhora de Atalaia era mais democrático, toda população podia participar da organização e compor o espírito da

Oficina do Historiador, Porto Alegre, EDIPUCRS, v. 7, n. 1, jan./jun. 2014, p. 202-207 205 
festa. Já o círio de Nossa Senhora do Cabo era sujeito à influência da Igreja e ao gosto da aristocracia, pois tinha forte relação com o mecenato da nobreza. Nesse sentido, no primeiro círio era possível notar maior presença de negros e um espírito mais popular da festa; já no segundo, foi possível notar o surgimento de manifestações literárias em virtude da participação da aristocracia.

As informações sobre o círio a Nossa Senhora de Atalaia datam a partir do século XVIII, quando a romaria ganhou relevância até o declínio no despontar do século XX. Este círio se tornou no século XVIII a mais popular manifestação devota de massa, graças à contribuição dos negros, que eram responsáveis pela criação do clima de grande festa popular que esses círios iriam assumir. Tinhorão assevera que as romarias que saiam de Lisboa eram as mais carnavalescas e, muito se deve à presença de negros, com seu espírito festivo, participando das diversas confrarias.

Nessas manifestações era possível notar a participação de negros escravos e forros em pé de igualdade com a sociedade branca local. Os negros tinham permissão tanto da Igreja quanto do Estado para participarem da sociedade, o que era visível com a permissão para criação da Confraria de Nossa Senhora do Rosário dos Homens Pretos no século XV. Nas confrarias, os negros tinham determinados direitos civis e eram de certa forma, tutelados pelo Estado.

As evidências históricas provam que isso acontecia pelo fato da Igreja e do Estado estarem envolvidos no tráfico de escravos. Os portugueses conciliavam a ética à violência, com o pretexto de inserir os negros na civilização e de estar levando aquelas almas para Cristo, assim, os salvando. Nesse momento surgiram oposições entre brancos e negros, uma disputa de espaços e direitos e, de acordo com os documentos oficiais, as intervenções eram em favor dos negros. Exemplo disso foi a permissão para a confraria angariar esmolas em Lisboa aos domingos. Havia, então, a participação dos negros em festas e solenidades oficiais em Portugal. Após 1640, a participação dos negros em festas oficiais ocorre por meio de danças típicas da África, o que quase sempre os tornavam uma atração exótica em festividades reais. $\mathrm{O}$ autor analisa que os tocadores negros de tambores e cornetas já faziam parte das coreografias das festas oficiais, assim como dos círios, que eram abertos às massas.

Outro círio tradicional em Portugal se deslocava para a Igreja de Nossa Senhora do Cabo. Valendo-se de fontes literárias, o autor afirma que as chegadas desse círio eram comemoradas também com muita festa, músicas e danças. E no arraial da igreja era montado um palco de representações populares de caráter cênico que dava singularidade a essa festa. Nesse círio, a participação dos negros era mais restrita, embora estes sempre fossem

Oficina do Historiador, Porto Alegre, EDIPUCRS, v. 7, n. 1, jan./jun. 2014, p. 202-207 206 
lembrados nas chamadas entradas (representações), um dos atos principais dessa festa, no qual a maioria dos exemplares encontrados foi escrita no nome de Frei Lucas de Santa Catarina. Nessas encenações sempre era comprovada a participação dos negros em tudo que o povo transformasse em festa, em Portugal. Mesmo que não se comprove que todas as entradas, farsas e loas tenham sido representadas durante a festa de Nossa Senhora do Cabo, seu realismo garante a qualidade de melhor fonte de informações da vida social das baixas camadas portuguesas no despontar dos Setecentos.

Segundo o autor, esse clima de festa já existia nas procissões, mas com a inserção dos negros, houve uma exacerbação desse clima de festa, um verdadeiro carnaval. Nesse sentido, a participação dos negros era uma garantia de características festivas. Tinhorão menciona que essa seria uma maneira deles compensarem a vida a qual eram sujeitos, portanto estavam sempre prontos para o riso e para a diversão. Esse espírito alegre e festeiro funcionava como subversão. As evidências históricas levam a concluir que existia uma tendência natural dos negros africanos a uma visão órfica da vida.

Em suma, com base na análise desenvolvida, Tinhorão evidencia que o uso do sagrado em detrimento do profano era uma particularidade da cultura popular portuguesa e que a participação dos negros, embora cercada de interesses políticos e religiosos, conferia característica única a essas manifestações - com suas músicas, danças, batuques e roupas coloridas -, como se o negro tivesse vocação para animar a festa. Esses cortejos apontam para uma presença negra na vida popular de Lisboa até meados do século XX. Entretanto, hoje, quase não se vê e não se lembra dessa presença, como uma tentativa de amnésia coletiva.

O livro apresenta leitura fácil, embora alguns trechos sejam excessivamente descritivos. Propõe discussões muito interessantes e valiosas, baseadas em fontes históricas nas quais o autor analisou a participação dos negros na sociedade lusitana, podendo, assim, observar questões políticas, econômicas, religiosas, culturais presentes nesses cortejos, para enfim, valendo-se dessa união de diferentes, formar uma síntese que resultaria na identidade nacional portuguesa. Sem dúvida, essa obra se torna relevante para os historiadores interessados em trabalhar com as diversas festas em suas singularidades, podendo assim, compreender de forma mais verticalizada a sociedade abordada.

RESENHA ENVIADA EM: 11.09.2013 ACEITA PARA PUBLICAÇÃO EM: 22.12.2013 